\title{
Conservative and Aesthetic Emergency Management in Adolescent with Complex Crown-Root Fracture and Simultaneous Oblique Root Fracture in Upper Maxillary Central Incisor: Clinical Outcome after 18 Months Follow-up Period
}

\author{
Manejo de Urgencia Conservador y Estético en Adolescente con Fractura Corono \\ Radicular Complicada y Fractura Radicular Oblicua Simultanea en Incisivo Central \\ Maxilar: Resultado Clínico después de 18 Meses de Seguimiento y Control
}

Jaime Díaz M., ${ }^{* * * *}$; Bárbara Hope L.** \& Alejandra Jans M. ${ }^{* * *}$

DÍAZ, J.A.; HOPE, B. \& JANS, A. Conservative and aesthetic emergency management in adolescent with complex crownroot fracture and simultaneous oblique root fracture in upper maxillary central incisor: clinical outcome after 18 months follow-up period. Int. J. Odontostomat., 6(1):27-37, 2012.

SUMMARY: Emergency treatment of 11- years-old female patient, presenting a complicated crown root fracture, which simultaneously presented oblique root fracture in the maxillary right central incisor. In order to expose the subgingival extension of the fracture, it was necessary to raise a mucoperiosteal flap. In light of pulp exposure, and prior to the repositioning of fragments with adhesive composite resin technique, Cvek pulp therapy was performed . Despite the existence of a 4-5 $\mathrm{mm}$ subgingival extension, neither surgical nor orthodontic extrusion of the root fragment was performed due to the presence of intra-alveolar oblique root fracture without displacement. Minimally invasive and conservative clinical management is basic, namely due to the great capacity of pulp healing in young permanent teeth, the absence of displacement between fragments of root fracture, and great capacity of adhesion and tensile strength of current adhesive systems. Clinical and radiographic controls over the first 18 months have shown an excellent pulp response, with some minor periodontal complications in relation to the biological width invasion and an adequate functional and aesthetic result.

KEY WORDS: Crown-root fracture.

\section{INTRODUCTION}

Nowadays, there has been an important and significant epidemiological increase in dental trauma all over the world, especially in scholar and adolescents group. The literature has stated the most common factors associated to dental trauma in theses group of patients: collision, contact sports activities, physical assault, traffic accidents, bicycle accidents and falls (Glendor, 2008; Traebert et al., 2003; Andreasen et al., 2007a).

In the past 12 years, the literature has informed a particularly high prevalence of dental injuries in children between 7 to 12 years of age (Glendor; Traebert et al.; Andreasen et al., 2007b; Marcenes, 1999). Throughout this youthful, energetic growing period, children are constantly exposed to new experiences and adventures, and are also more prone to accidents, especially dental injuries. In both dentitions the most affected teeth are the upper maxillary central incisors. Crown fractures and luxations of the upper anterior region are the most frequently seen (Petersson, 1997).

Crown-root fracture (CRF) has been described

\footnotetext{
Undergraduate Paediatric Dentistry Programme, Dental Department, Faculty of Medicine, Universidad de La Frontera, Temuco, Chile.

** Undergraduated Paediatric Dentistry student, Dental Department, Faculty of Medicine, Universidad de La Frontera, Temuco, Chile.

*** Dental Service, Paediatric Dentistry Specialty, Temuco Regional Hospital, Temuco, Chile.

${ }_{* * * *}^{*}$ Paediatric dentist, Dental department, Faculty of Medicine, Universidad de La Frontera, Temuco, Chile.
} 
in dental literature as one of the dental injuries of the hard tissues of young permanent teeth. In this type of injury, the affected tooth presents enamel, dentin and cementum compromise. In cases where pulp involvement is present, it is considered as an important complicating factor (Andreasen et al., 2007a). CRF is a very traumatic experience to the young patient and their parents. Clinically, the usual appearance of this dental injury is a luxation of the coronal fragment with a range of severity. The compromised tooth presents increased mobility and bleeding from the periodontal ligament and/ or directly from the exposed pulp tissue, or from injuries of the neighboring soft tissues. The patient reports pain during occlusion. The coronal fragment may be attached to the alveolar socket only by minimal gingivoperiodontal fibers, or knocked out from it (Flores et al., 2007). As in root fractures, more than one radiographic examination with different angles may be necessary to detect fracture lines in the root. In some cases, the radiographic examination does not detect the complete direction of fracture lines, making the diagnosis even more difficult and complex. Since CRF may involve all dental tissues, it should be assessed and properly treated by an interdisciplinary staff of dentists (Heda et al., 2006; Santos Filho et al., 2007). Oblique crown-root fractures that extend below the gingival margin and the alveolar bone, involving enamel, dentine and pulp are difficult to restore. Nevertheless, the current knowledge on dental traumatology and the interdisciplinary management of complex trauma cases, allow the possibility for success (Andreasen et al., 1989).

In addition to the immediate consequences after a CRF to the upper maxillary incisors, such as pain and bleeding, delayed complications like alteration in physical and aesthetic appearance, speech defects, social and functional problems, and the psychological and emotional impact that will affect the children and adolescent quality of life, should be considered (Alonge et al., 2001; Marcenes).

Literature shows various and different alternatives to emergency treatment of CRF in permanent teeth, where the aesthetic and the patient's comfort are severily compromised. The treatment modalities can be altered depending on the location of the fracture line and the amount of remaining root (Andreasen \& Andreasen, 1994). Published treatment options for such cases include: (i) orthodontic or surgical extrusion (Bondemark et al., 1997), (ii) gingivectomy and osteotomy/ osteoplasty (Andreasen \& Andreasen, 1991), (iii) intentional replantation (Grossman, 1966), and (iv) extraction. In terms of aesthetic and fracture resistance, there are several researches that establish the advantages regarding the use of the original crown and crown-root fragments over composite restorations (Yilmaz et al., 2010; Dos Santos et al., 2010). The following case report outlines a conservative, minimally invasive and aesthetic emergency approach of an upper right central incisor with an uncommon combination of complex complicated crown-root fracture (C-CRF) along with a third-middle oblique root fracture in an 11-year-old female patient. The clinical and radiographic outcome after an eighteen month follow-up period is showed.

\section{CASE REPORT}

An eleven-year-old female patient seeks urgent dental care at the Hernán Henríquez A. Regional Hospital of Temuco, Chile, in May of 2010. About 45 minutes earlier, while in school, she fell in the backyard, causing severe dental trauma to both upper maxillary central incisors. At first, she is evaluated by a maxillofacial surgeon, who provides first aid assistance, which includes suture of a cut on the lower lip, cleansing of the affected area with saline and clorhexidine, and the application of a temporary oxide zinc eugenol (ZOE) filling on tooth 1.1. In these conditions, the patient is referred to the Pediatric Dentistry Clinic of the Faculty of Medicine, Universidad de La Frontera, IX Region, Temuco, Chile.

The patient is evaluated at the Unit of Pediatric Dentistry later that day. Clinical examination shows remains of the temporary ZOE cement over an area of exposed dentin in tooth 1.1 due to the fracture, with a deep-wide-oblique crownroot fracture that extends below the gingival margin, on the vestibular and distal aspects. Clinically, the diagnosis corresponded to crown-root fracture (CRF). Tooth 2.1 shows non-physiological mobility and appears extruded (1 to $2 \mathrm{~mm}$ ), with evident bleeding from the gingival margin and extremely sensitive to axial percussion test (Fig. 1). The patient's mother had saved the crown's missing fragments in a glass of water (Fig.2). 


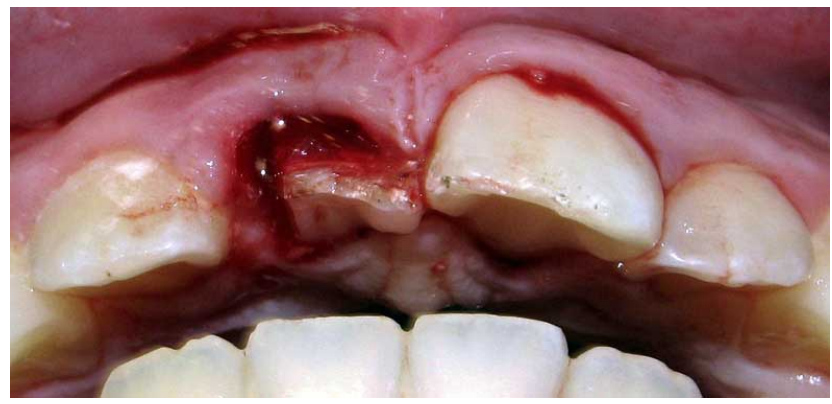

Fig. 1. Pre-operative clinical view of tooth 1.1 with a deep extensive crown-root fracture. Tooth 2,1 shows bleeding from the gingival margin, indicative of a luxation injury.

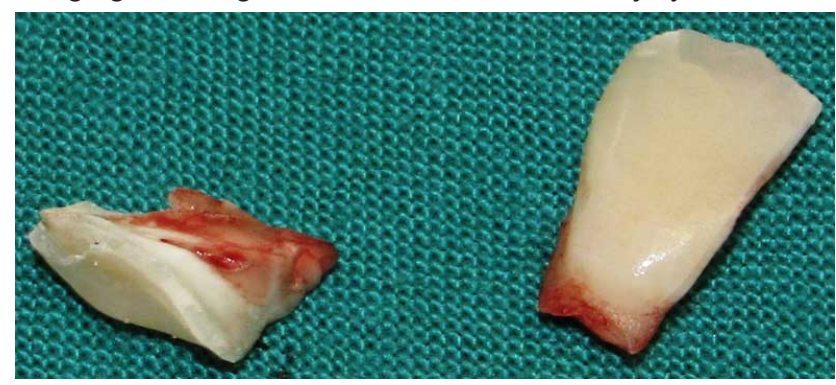

Fig. 2. Clinical aspect of the two recovered crown-root fragments prior to the reattachment procedure.

Radiographic examination shows an oblique CRF on tooth 1.1, with an additional oblique intra-alveolar root fracture (RF) between the middle and apical thirds, with no movement or displacement of the coronal fragment. Tooth 2.1 shows apical periodontal space widening, consistent with an extrusive luxation (Fig.3).
After obtaining medical and dental history, the emergency treatment is planned. It includes: (i) Lifting of a mucous flap to expose the subgingival aspect of the fracture. At this point, it is possible to see that the fracture extends up to $4-5 \mathrm{~mm}$. below the gingival margin. While removing the temporary ZOE filling, an area of pulp exposure becomes evident (complicated crown-root fracture / C-CRF), enhancing the difficulty of the clinical scenario (Fig.4). (ii) Due to the short amount of time since the exposure, a Cvek's partial pulpotomy is performed. Haemostatic maneuvers are performed, and the area is sealed with calcium hydroxide (Dycal $®$, Dentsply USA). (iii) Once a dry clinical field is accomplished, the missing fragment's reposition is performed, using composite adhesive technique (Filtek Z- 350®, 3M ESPE) and a celluloid preformed crown matrix. (iv) After the crown is restored, flap repositioning and suture of the area (vycril ${ }^{\circledR} 4 / 0$, Johnson \& Johnson) is performed. (v) Finally, tooth 2.1 is repositioned digitally and stabilized using a flexible wire-composite splint. (vi) The postoperative indications given to the patient include: soft diet, local ice, painkiller prescription and immediate X-Ray examination, which showed an appropriate adaptation of the crown-root fragment and no displacement of the root fracture (Fig.5).

After 30 days of follow up, the patient complaints of a mild discomfort to the axial percussion test on tooth 2.1. Given the extrusive luxation diagnosis, loss of pulp vitality is suspected, and a pulpectomy is scheduled, along with the referral to an endodontist. However, while performing the procedure, pain and hemorrhage are present, indicating pulp vitality. Thus, a direct pulp capping therapy with calcium hydroxide is performed, and the area is sealed with composite-resin restoration.

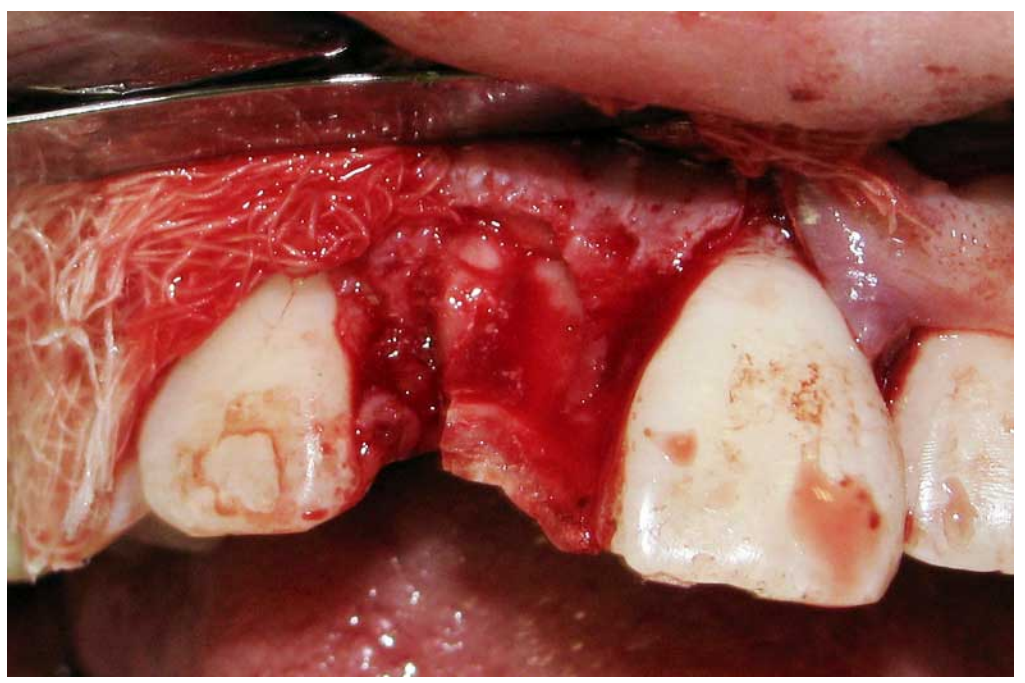

Fig. 4. Clinical view of the mucoperiosteal flap lifting in tooth 1.1; observe the depth of the crown-root fracture, and the pulp exposure in the center.
2.1 a discrete widening of periodontal and apical space is observed. 


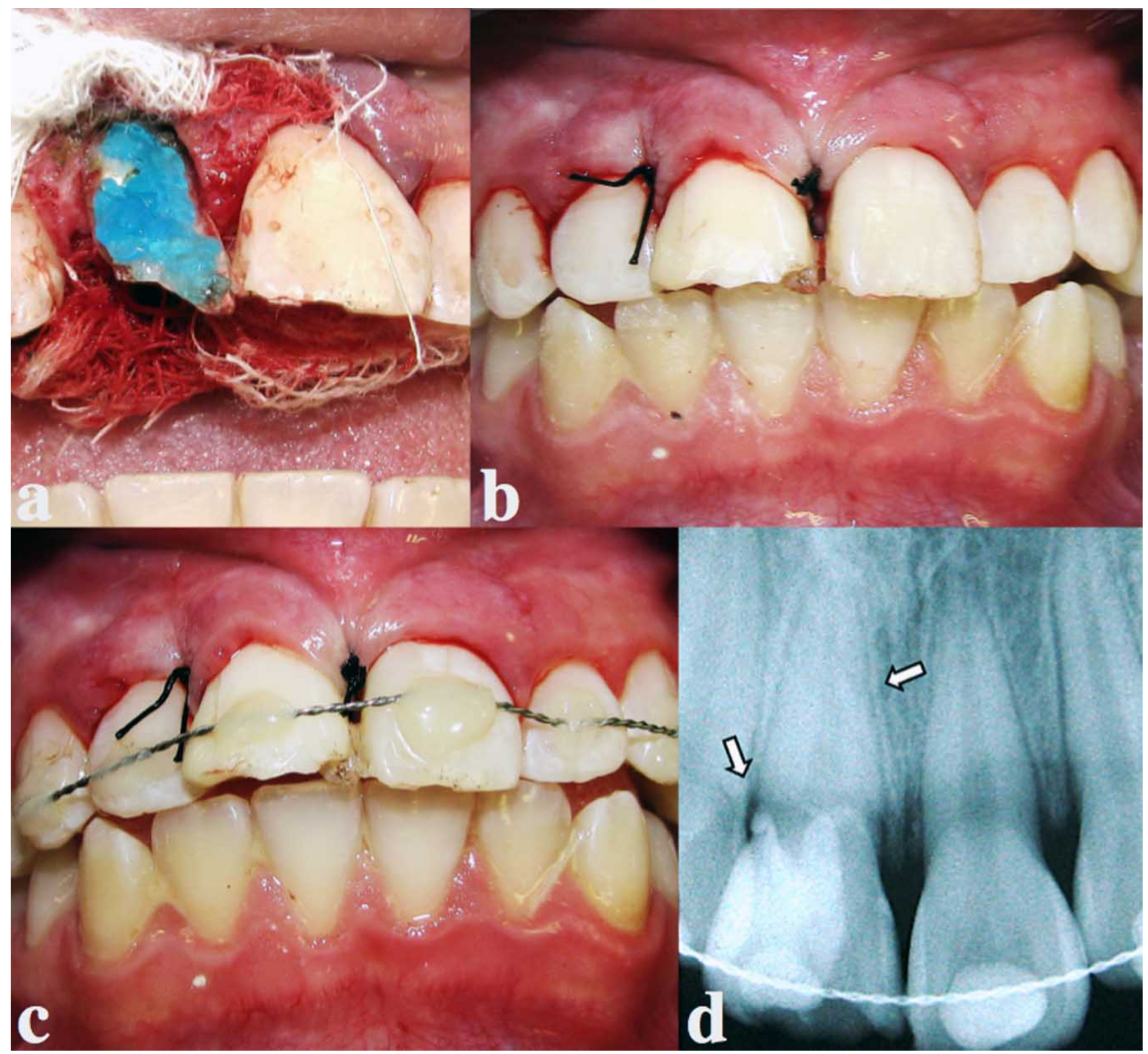

Fig. 5: Different stages of coronal fragment reattachment procedure. a. Dentin and enamel surface etching with orthophosphoric acid. b. Crown-root fragment repositioned with composite resin. c. Stabilization of the compromised teeth with flexible wirecomposite splint. 4. Immediate radiographic control of the upper right central incisor. Observe the adjustment between the fragments, the extension of partial pulpotomy and oblique third-middle root fracture without displacement.

After 3 months of follow up, tooth 1.1 shows nonphysiologic mobility and active fistulae 4 to 5 millimeters above the gingival margin. However, percussion test is negative, and on the vestibular aspect, the depth probing test indicates a periodontal pocket of $5 \mathrm{~mm}$ (Fig.6). A gentile root planning and clorhexidine rinse is performed, and the process ceases. Five months after the accident (October 2010), the fistulae reappear on the same location. Radiographic examination does not indicate external root resorption, and shows no complications of the oblique fracture healing process (Fig. 7).
Given the reappearance of the fistulae, and after her parents signed the informed consent, the patient was brought back to the operating room for an exploratory surgery. After lifting a mucoperiosteal flap from teeth 1.2 to 2.2, an area of root disruption along with granulation tissue is observed where the crownroot fracture junction was taking place. Root scaling of the compromised area was performed; it was cleansed with glucosaline solution and clorhexidine, and then sealed with resin-modified glass-ionomer cement (RMGIC, Vitremer ${ }^{\circledR}, 3 M$ ESPE) (Fig. 8). 


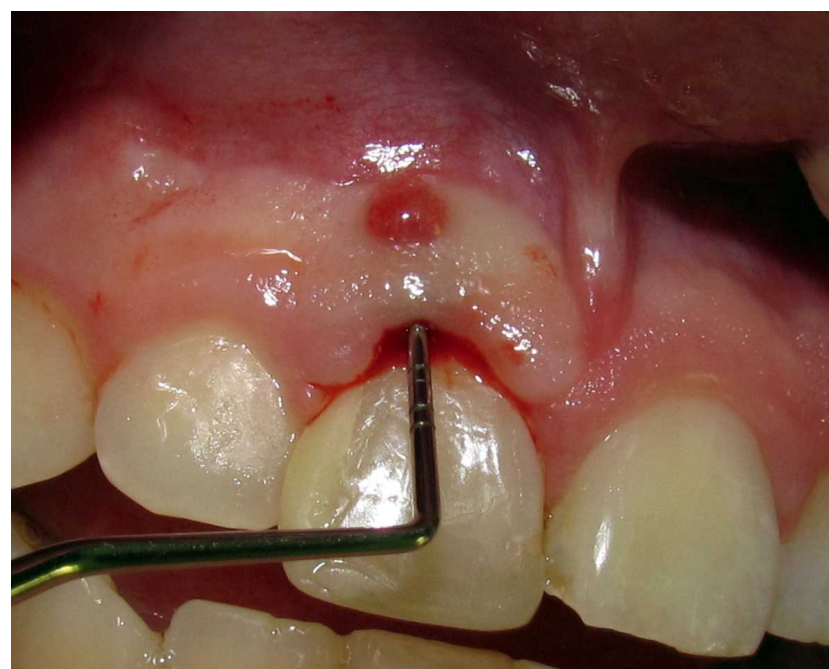

Fig. 6. Clinical aspects 3 months later; note the marked inflammation of the gingival margin, fistulae and the presence of $5 \mathrm{~mm}$ periodontal pocket depth.

Seven months after the exploratory surgery (May 2011) a new root planning is performed due to the presence of gingival edema and bleeding. After 15 months (July 2011) of clinic and radiographic followup, tooth 1.1 hasn't shown any pulp abnormalities, no increased volume in the vestibule, presents physiologic mobility, and the periodontal pocket has remained at 3-4 $\mathrm{mm}$. Minor aesthetic adjustments had been made to the resin composite restoration. The periodontist indicated oral hygiene reinforcement and regular use of dental floss. At the last radiographic examination ( October 2011), tooth 1.1 presented adequate signs of root fracture healing with partial pulp obliteration in apical fragment, a radiopaque image compatible with hard tissue barrier at site of partial pulpotomy and normality of all support structures. At the same

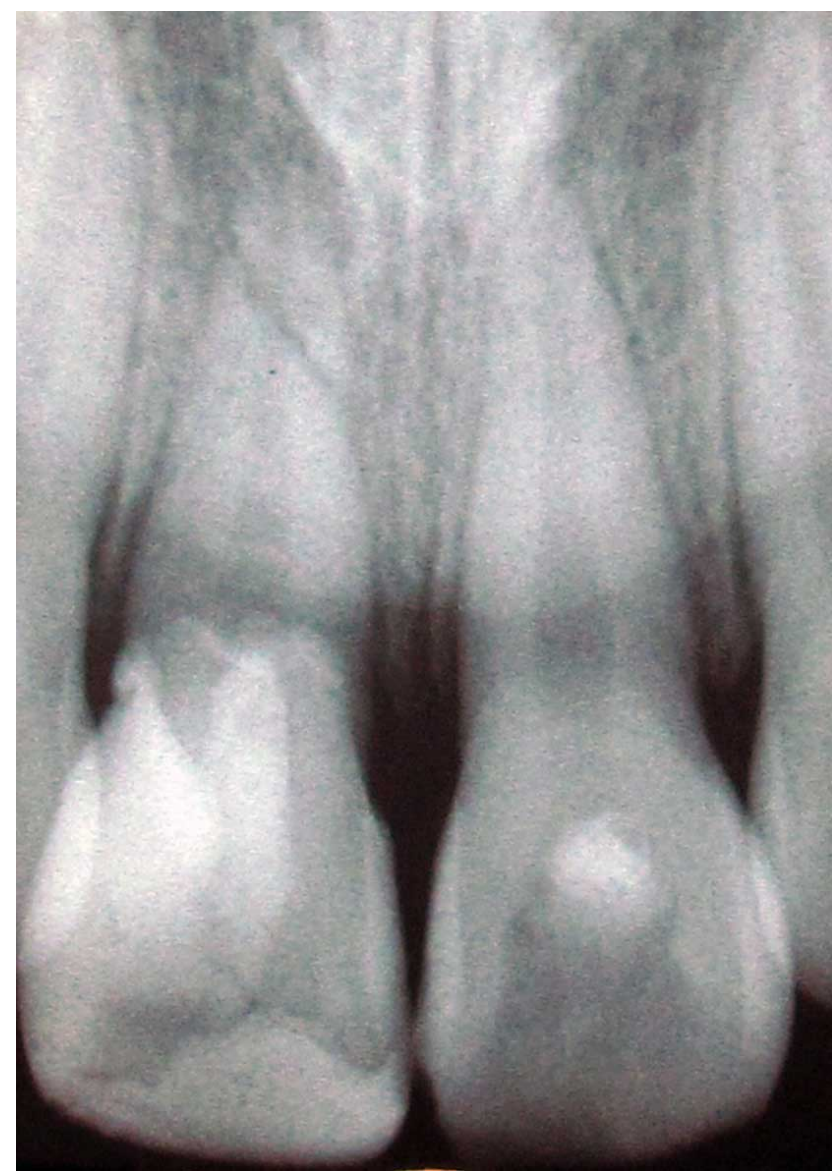

Fig. 7. Five months postoperative radiographic control shows appropriate healing of the root fracture and no signs of alveolar bone compromise or external root resorption.

examination, tooth 2.1 shows images compatible with internal surface resorption (ISR) and internal tunneling resorption (ITR) (Fig. 9). Simultaneously, cone-beam computed tomography (CBCT) examination was

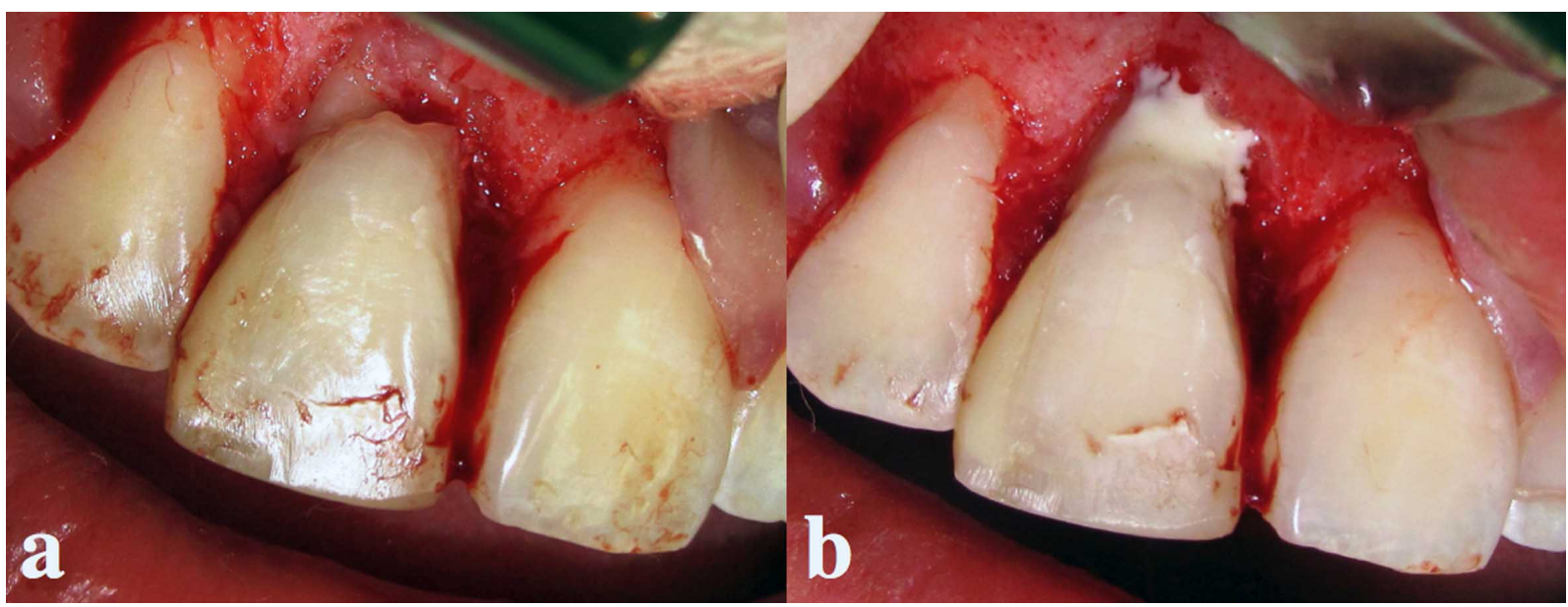

Fig. 8. a. After lifting a mucoperiosteal flap, the defect between the fracture's fragments and the presence of granulation tissue in the area is observed. b. After root scaling, the sealing of the fracture defect is performed wtih R-MGIC. 


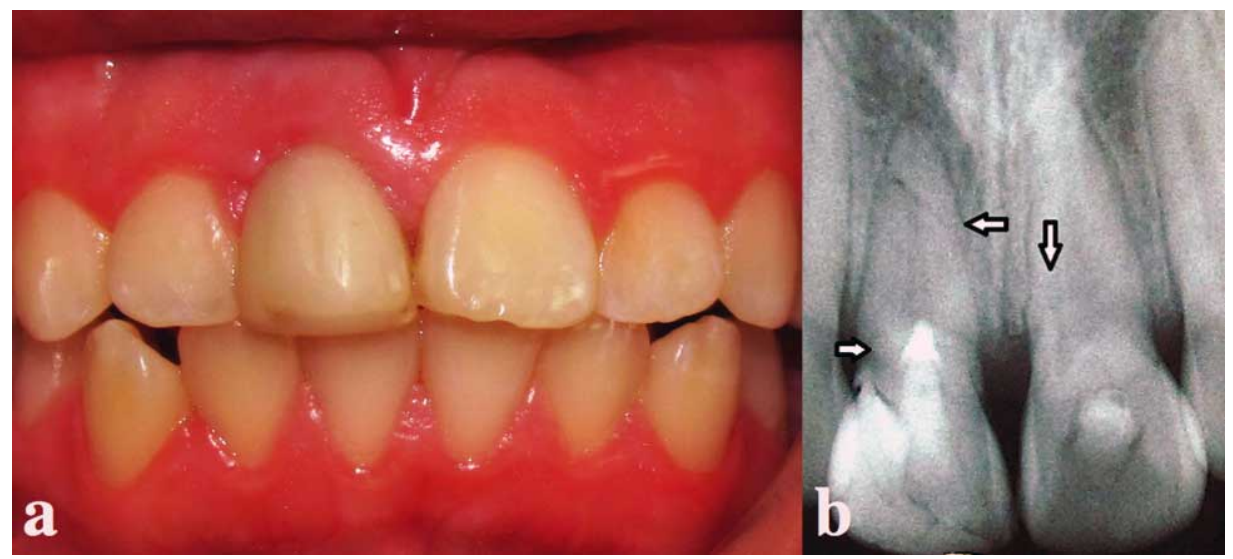

Fig. 9. a. Clinical view 18 months after de accident. Tooth 1.1 shows adequate gingival tissue status, no signs of bleeding and satisfactory aesthetic results. b. Radiographic examination at the same session shows healing of root fracture and supporting tissues. Tooth 2.1 shows image of internal surface resorption (ISR) and internal tunneling resorption (ITR) performed (Pax-Zenith 3D, Vatech Co. Ltd., GyeonggiDo, Korea; 2010). It showed three-dimensional (3D) images close to the reality in greater detail and different aspects, and structural changes of healing process in both compromised teeth. There is a remarkably wide internal resorption in tooth 2.1 and the real extension and direction of CRF and RF in tooth 1.1. (Fig.10).

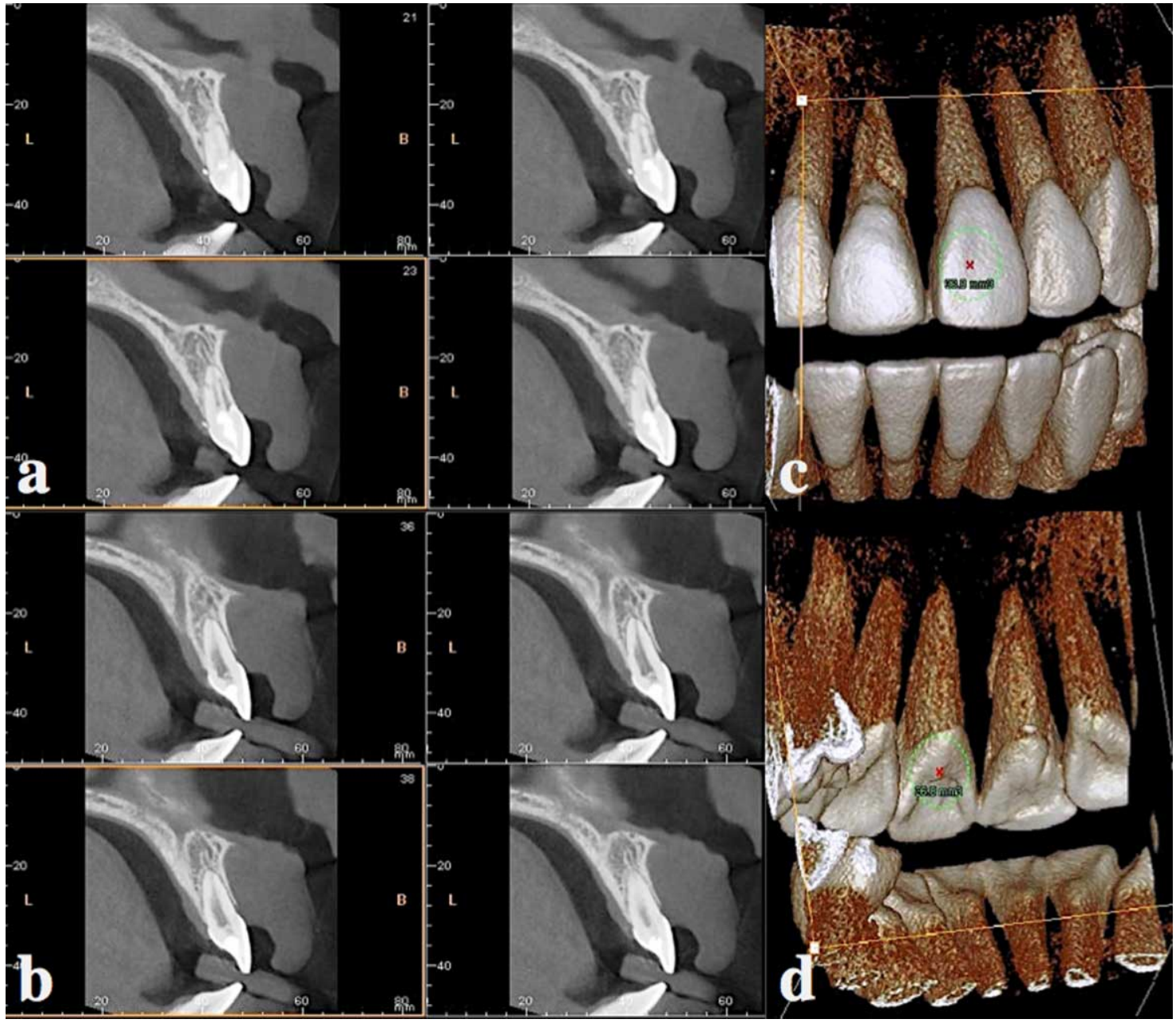

Fig. 10. a. Series of cross-sectional $0.5 \mathrm{~mm}$ cuts showing the extension, direction and location of RF and CRF. In tooth 1.1,the image shows clearly horizontal root fracture with an oblique component in the palatal aspect of the root. At the same view, observe the extension of CRF with oblique direction toward vestibular root surface. b. Cross-sectional $0.5 \mathrm{~mm}$ cuts showing wide internal root resorption with palatal extension in tooth 2.1. c-d. $3 \mathrm{D}$ visualization of tooth 1.1 that shows the exact location, extension and direction of RF and CRF. 
DÍAZ, J.A.; HOPE, B. \& JANS, A. Conservative and aesthetic emergency management in adolescent with complex crown-root fracture and simultaneous oblique root fracture in upper maxillary central incisor: clinical outcome after 18 months follow-up period. Int. J. Odontostomat., 6(1):27-37, 2012.

\section{DISCUSSION}

Traumatic dental injuries in children with young permanent dentition necessarily involve function, aesthetics and psychological aspects. The different lesions may range from minimal crown fractures to complex crown-root fractures.

When faced with a maxillary incisor with CRF, especially in adolescents, the correct diagnosis is of utmost importance to establish a prognosis as real as possible, and avoid overtreatment. However, the aesthetic aspects and outcome of the emergency management and posterior treatment should be considered, especially in adolescents aged 11-15. Therefore, the crown-root fragment re-attachment operative procedure must be considered and evaluated like a real alternative therapy.

This situation is critical when the patient brings the tooth's fragments. Until today, there are several questions with regard to the most appropriate treatment for children and adolescents with crown and CRF (Castro et al., 2005). Of course, in these complex clinical cases, the definition of a rational appropriate emergency therapy requires the establishment of an accurate diagnosis and prognosis, because aesthetics and self-esteem are at stake.

Although the incidence of dental trauma has reached epidemiological levels over the past few years, adequate knowledge and emergency management of CRF is considered rare among dentists (Marcenes, 2000; Hu et al., 2006). Moreover, CRF remains as a challenging clinical situation, because of the difficulty to perform a correct diagnosis and treatment, due to the need of a multidisciplinary approach (Castro et al.).

Complicated crown-root fractures (CCRF) are the most difficult dental injuries to be treated; which is supported in the dental literature that shows significant differences between the treatments offered by dentists possibly related to commitment of the periodontal biological width. In general, the literature shows three treatment modalities for CRF: (i) fragment reattachment, (ii) composite resin build-up restoration, and (iii) full crown coverage (Andreasen et al., 2007b; Flores et al., 2007). The loss of maxillary incisors in children and young population results in a variable reduction in alveolar bone mass with a considerable impact on future treatment options (implants and resin bonded bridges). Given this complication, in cases of CRF where prognosis is poor or later rehabilitation is not possible, some authors have stated as an alternative to extraction, to leave the submerged root fragment in order to preserve bone tissue for a future dental implant (Olsburgh et al., 2002; Mackie \& Quayle, 1992).

The restitution of aesthetics, original crown anatomy and function are the main objectives that a dentist should accomplish when facing CRF in adolescent patients. In this context, the re-attachment of the crown-root fragments is of major importance.

The different techniques and quality of bond strength of dental crown fragment's reattachment have been widely discussed in dental literature (Olsburgh et al.; Mackie \& Quayle; Rappelli et al., 2002; Demarco et al., 2004; Farik et al., 2002). Overall, it presents important advantages over composite resin restorations: (I)simple procedure,(ii) minimally invasive, (iii) short time of treatment and immediate re-establishment of aesthetics and function,(iv) exact morphology and texture, (v) similar look to adjacent/ opposed teeth, (vi) color match with the rest of the tooth's crown, (vii) preserved incisal translucency and tooth contours and (viii) delay in the "prosthetic restoration" for young patients (Olsburgh et al.; Rappelli et al.; Murchinson et al., 1999).

Usually, CRF presents a single fracture line; multiple fractures are less common. The treatment is easier to perform when the affected tooth presents a single crown root fragment, ideally of a size large enough to allow proper handling, and sharp edges that enables proper adaptation and adhesion to the remnant tooth. Obviously, the technique is more complex and questionable in the presence of multiple tooth fragments.

In this case, different factors were taken into consideration for the reattachment of the remnant crown-root fragments: (i) the fragments presented regular edges and an adequate adaptation to the root portion, (ii) although one of the 3 fragments got lost at the place of the accident, the 2 remnant fragments were susceptible for reattachment with composite resin restoration, (iii) lift the mucoperiosteal flap after, a pulp tissue exposure was observed, partial pulpotomy was performed. The reattachment of the fragment allowed an excellent sealing of the fracture line and the pulp exposure, avoiding the contamination of the underlying pulp tissue. 
Is partial pulpotomy the appropriate therapy in patients with complicated CRF (C-CRF) in upper permanent incisors? Most records of C-CRF therapy in maxillary permanent incisors included pulpectomy and endodontic treatment, because the root canal is likely to be used to locate a post that will provide attachments for a future prosthetic restoration (Andreasen, 2007a; Andreasen et al., 2002; Monteiro de Castro et al., 2010). During immediate treatment and follow up sessions for CRF, the specialist should consider the possibility of endodontic and periodontal compromise, as well as the invasion of periodontal biological space and the location of the fracture lines. In the study of Monteiro de Castro, all respondents confirmed that C-CRF requires endodontic therapy to allow a good outcome. This study also confirmed that CRF presents the most difficulties for dentists to establish an adequate treatment, because these fractures require multidisciplinary knowledge and approach for a correct case planning and prognosis.

However, our intention in this case was to perform a conservative and minimally invasive therapy, given that the accident had occurred only 4 hours prior, the pulp tissue presented normal bleeding, without signs of irreversible pulpitis and/or pulp necrosis, and the affected tooth had no previous caries or restoration history. We also considered the fact that we were dealing with an 11-year-old patient with high vascular and cellular pulpar properties, which provided a good defense mechanism and healing potential.

Raslan \& Wetzel (2006). showed that teeth with pulp exposure after crown fracture presented fewer inflammatory cells in the root canal in comparison with those with pulp exposure caused by caries, and concluded that teeth with traumatic pulp exposure were more likely to respond positively to the pulpotomy technique.

According to the results of Fucks et al. (1987), partial pulpotomy is the treatment of choice in permanent teeth with dental trauma and pulp exposure, regardless of the size of the exposure, the time interval until the emergency treatment, or the degree of root development, as long as the pulp is vital and shows no signs of pulp necrosis.

Furthermore, in spite of the middle third oblique concomitant root fracture, the root's coronal fragment suffered no displacement, and there was no commotion in the pulp circulation between the fragments, allowing an adequate blood supply for the subsequent pulp healing process. The inflammatory phenomenon is usually transitory, as long as pulp vascularization remains intact. In this context, an earlier and suitable first emergency attention to achieve a correct protection and sealing of the pulp tissue is of main importance. In accordance to these fundamentals, it was defined to perform the crown-root fragment reattachment, and wait for root fracture healing with connective or hard tissue. After eighteen months of clinical and radiographic follow-up, there have been no signs or symptoms of pulp complications and no healing complications have been observed at the oblique root fracture.

Nowadays, while planning the treatment, it is important not to forget the favorable evolution of adhesive materials over the years, providing the necessary bond-strength between the fragments to allow a favorable outcome (Demarco et al.; Sengun et al., 2003). In terms of the cytotoxicity of adhesive systems and the acute pulp inflammatory reaction they generate when applied in deep dentin preparations, until today, the pulp healing process in our patient has been adequate, probably due to the protective action provided by the coating materials used to isolate the pulp during the partial pulpotomy procedure.

In this particular case, orthodontic or surgical extrusion of the affected tooth were not considered as feasible treatment options, because of the presence of the middle-third oblique root fracture without displacement, which contraindicated the extrusion procedure. Either one of these techniques would generate a separation between the fragments, resulting in stretching or sectioning of the root's pulp tissue, and the consequent loss of vitality.

The different types of root fracture healing in permanent teeth have been widely documented in dental literature. In general, when there is no displacement of the coronal root fragment, in young permanent teeth the fracture's healing prognosis is good (Andreasen et al., 2007a; Andreasen et al., 1989; Cvek et al., 2001;Andreasen et al., 2004;Cvek et al., 2008) Our patient's postoperative radiographs confirm the above, showing an image compatible with healing by interposition of connective tissue.

Even though crown lengthening surgery has been recognized as the most effective treatment for biological width recovery in cases of tooth fractures that extends close to or deeper than the alveolar bone margin, in this case it was ruled out because aesthetics 
DÍAZ, J.A.; HOPE, B. \& JANS, A. Conservative and aesthetic emergency management in adolescent with complex crown-root fracture and simultaneous oblique root fracture in upper maxillary central incisor: clinical outcome after 18 months follow-up period. Int. J. Odontostomat., 6(1):27-37, 2012.

would be seriously compromised (Baratieri et al.,1990; Baratieri et al., 1993). When the treatment choice is the reattachment of a crown fragment with adhesive technique, the surgical and orthodontic extrusion is contraindicated, because it would alter the incisal line, because the crown anatomy and the exposure of the cervical -third portion of the root is not harmonious with the cervical-third crown portion of neighboring frontal teeth.

The presence of the 4-5 $\mathrm{mm}$ periodontal pocket can be explained by the invasion of the biological width by the crown root fracture line, and to the slight mismatch between the fragments under the gingival margin. In this case, the periodontist's assessment suggested checking the patient on follow up sessions and performing a gentile root planning if necessary.

There are records in the literature with regard to the advantages of using Resin-modified glass ionomer cements (R-MGIC) in cases of reattachment of tooth fragments with invasion of biological width (Baratieri et al., 1993; Dragoo, 1997). Based on these results, we selected Vitremer® (3M/ESPE) as our R-MGIC of choice. After the 2nd root planning, Vitremer $\mathbb{B}(3 \mathrm{M}$ ESPE) was located over de fracture line, smoothing the area by filling the mismatch spaces between the fragments. Reduction in gingival edema and bleeding has been observed.

Given that this technique is more conservative, we believe that in children and adolescents less than 15 years of age, it should be considered as an alternative prior to a prosthetic restoration. It is known that the alveolar bone resorption in an inevitable and undesirable consequence of tooth loss and present inter-individual variability (Gomes, 2005). It is necessary to explain to the patient the semi-permanent or longterm provisional restoration character of this treatment; that it represents a solution until the end of the tooth's development and stabilization of the oclusion. On the long term scale, if in the future the treatment fails, the maintenance or intentional retention of maxillary root fragment will have provided an appropriate alveolar ridge, allowing treatment with dental implants.

Regarding tooth 2.1, which presents at latest radiographic examination an internal surface resorption (ISR) and internal tunneling resorption (ITR), our approach is conservative, because we should expect complete pulp healing during 1-2 years after the injury. According to Andreasen et al., during the initial stages of pulp healing, hard dental and pulp tissues of traumatized permanent teeth can stimulate an inflammatory response, and initiate the release of osteoclast activating factors. The emergence and develop of these root resorption processes usually are seen within the first year after injury, presents a very low frequency in luxated permanent teeth, are selflimiting in time, require no treatment and precede the pulp healing and the development of pulp obliteration (Rodd et al., 2007; Andreasen et al., 2007a; Andreasen, 1989; Andreasen et al., 1988).

The complementary examination of teeth affected by dental trauma and the complications (pulp necrosis, $\mathrm{PCO}$, periapical pathosis, root resorption) generally are performing with periapical and oclusal radiographs. Unfortunately, these intraoral examination techniques provides poor sensivity in the detection of extension, direction and location of healing and resorption processes, due to the projection geometry, superimposition of anatomic structures and processing errors. However, the introduction of cone beam computed tomography (CBCT) has allowed new diagnostic possibilities in dental trauma and its resorption complications. CBCT offers the advantage of $3 \mathrm{D}$ visualization of the resorption root surfaces and allows determining the exact characteristics of the resorption. The better diagnostic capacity of three-dimensional imaging, allows that treatment planning becomes easier and more accurate (Cohenca et al., 2007).

\section{CONCLUSION}

The functional and aesthetic recovery in young patients with C-CRF represents a challenge for dentists, who should be well prepared and in constant updating, in order to provide the best emergency treatment possible. In the present case, the reattachment of subgingival crown root fragments was found to be clinically successful after 18 months of the treatment. With the improvement of etched-bonding agents, the re-establishment of function and aesthetics through a conservative and minimally invasive therapy that avoids additional damage by following biologic principles should be mandatory. We believe that an immediate effective emergency treatment of C-CRF during the same day of the accident is of the most importance for a good prognosis and a satisfactory aesthetic outcome. Adolescents affected with this type of dental trauma should be periodically scheduled for follow up evaluations. 
DÍAZ, J. A.; HOPE, B. \& JANS, A. Manejo de urgencia conservador y estético en adolescente con fractura corono radicular complicada y fractura radicular oblicua simultanea en incisivo central maxilar: resultado clínico después de 18 meses de seguimiento y control. Int. J. Odontostomat., 6(1):27-37, 2012.

RESUMEN: Se presenta el tratamiento de emergencia de una adolescente, sexo femenino, de 11 años de edad que sufre una fractura corono radicular complicada compleja, y que en forma simultánea presenta fractura radicular oblicua en incisivo central superior derecho. Para exponer la extension subgingival de la fractura, fue necesario levantar un colgajo mucoperióstico. Debido a la exposición pulpar, y previo a la reposición de fragmentos con técnica adhesiva de resina composite, se realizó una terapia pulpar de Cvek. A pesar de existir una extensión subgingival de 4-5 mm, no se realizó la extrusión quirúrgica ni ortodóncica del fragmento radicular debido a la presencia de fractura radicular oblicua intra-alveolar sin desplazamiento. El manejo clínico conservador y de mínima invasión es fundamentado principalmente por la alta capacidad de de cicatrización pulpar en dientes permanentes jóvenes, la ausencia de desplazamiento entre los fragmentos de la fractura radicular, y la alta capacidad de adhesión y resistencia a la tracción de los sistemas adhesivos actuales. Los controles clínicos y radiográficos durante estos primeros18 meses han mostrado una excelente respuesta pulpar, solo algunas complicaciones periodontales menores en relación a la invasión del ancho biológico y una adecuado resultado funcional y estético.

\section{PALABRAS CLAVE: Fractura corono radicular.}

\section{REFERENCES}

Alonge, O. K.; Narendran, S. \& Williamson, D. D. Prevalence of fractured incisal teeth among children in Harris County, Texas. Dent. Traumatol., 17:218-21, 2001.

Andreasen, F. M. \& Andreasen, J. O. Resorption and mineralization processes following root fracture of permanent incisors. Endod. Dent. Traumatol., 4: 202-14, 1988.

Andreasen, F. M.; Andresen, J. O. \& Bayer, T. Prognosis of rootfractured permanent incisors-prediction of healing modalities. Endod. Dent. Traumatol., 5:11-22, 1989.

Andreasen, F. M. Pulpal healing after luxation injuries and root fracture in the permanent dentition. Endod. Dent. Traumatol., 5:111-31, 1989.

Andreasen, J. O. \& Andreasen, F. M. Dental trauma, quo vadis. Tandlaegebladet, 93(11):381-4, 1989.

Andreasen, J. O. \& Andreasen, F. M. Essentials of traumatic injuries to the teeth. 1st ed. Copenhagen, Munksgaard, 1991. p.p. 47-62.

Andreasen, J. O. \& Andreasen, F. M. Crown-root fractures. In: Andreasen, J. O. \& Andreasen, F. M. (eds). Textbook and Color Atlas of Traumatic Injuries to the Teeth. Copenhagen, Munksgaard, 1994. pp. 257-77.

Andreasen, J. O.; Andreasen, F. M.; Skeie, A.; Hjørting-Hansen, E. \& Schwartz, O. Effect of treatment delay upon pulp and periodontal healing of traumatic dental injuries; a review article. Dent. Traumatol., 18:116 -28, 2002.

Andreasen, J. O.; Andreasen, F. M.; Mejare, I. \& Cvek, M. Healing of 400 intra-alveolar root fractures. 2 Effect of treatment factors such as treatment delay, repositioning, splinting type and period and antibiotics. Dent. Traumatol.; 20:203-11, 2004.
Andreasen, F. M.; Andreasen, J. O. \& Cvek, M. Root fractures. In: Andreasen, J. O.; Andreasen, F. M. \& Andersson, L. (editors). Textbook and Color Atlas of Traumatic Injuries of the Teeth. 4th Ed. Blackwell Munksgaard, Copenhagen, 2007a. p.p. $337-71$.

Andreasen, F. M. \& Andreasen, J. O. Luxation injuries of permanent teeth; General Findings. In: Andreasen, J. O.; Andreasen, F. M. \& Andersson, L. (editors). Textbook and Color Atlas of Traumatic Injuries of the Teeth. 4th Ed. Blackwell Munksgaard, Copenhagen, 2007b. p.p. 372-403.

Baratieri, L. N.; Monteiro Júnior, S. \& Andrada, M. A. C. Tooth fracture reattachment: case reports. Quintessence Int., 21:261-70, 1990.

Baratieri, L. N.; Monteiro Júnior, S.; Cardoso, A. C. \& Melo Filho, J. C. Coronal fracture with invasion of the biological width: a case report. Quintessence Int., 24:85-91, 1993.

Bondemark, L.; Kurol, J.; Hallonsten, A. L. \& Andreasen, J. O. Attractive magnets for orthodontic extrusion of crown-root fractured teeth. Am. J. Orthod. Dentofacial. Orthop., 112:18793, 1997.

Castro, J. C. M.; Poi, W. R.; Manfrin, T. M. \& Zina, L. G. Analysis of the crown fractures and crown-root fractures due to dental trauma assisted by the Integrated Clinic from 1992 to 2002. Dent. Traumatol., 21:121-6, 2005.

Cohenca, N.; Simon, J. H.; Mathur, A. \& Malfas, J. M. Clinical Indications for digital imaging in dento-alveolar trauma. Part 2: root resorption. Dent. Traumatol., 23:105-13, 2007.

Cvek, M.; Andreasen, J. O. \& Borum, M. K. Healing of 208 intraalveolar root fractures in patients aged 7-17 years. Dent. Traumatol., 17:53-62, 2001.

Cvek, M.; Tsilingaridis, G. \& Andreasen, J. O. Survival of 534 incisors after intra-alveolar root fracture in patients aged 7-17 years. Dent. Traumatol., 24: 379-87, 2008. 
DÍAZ, J.A.; HOPE, B. \& JANS, A. Conservative and aesthetic emergency management in adolescent with complex crown-root fracture and simultaneous oblique root fracture in upper maxillary central incisor: clinical outcome after 18 months follow-up period. Int. J. Odontostomat., 6(1):27-37, 2012.

Demarco, F. F.; Fay, R-M.; Pinzon, L. M. \& Powers, J. M. Fracture resistance of re-attached coronal fragments-influence of different adhesive materials and bevel preparations. Dent. Traumatol., 20:157-63, 2004.

Dos Santos, P.; Negri, M. R. \& Masotti, A. S. Rehabilitation to crown-root fracture by fragment reattachment with resinmodified glass ionomer cement and composite resin restoration. Dent. Traumatol., 26:186-90, 2010.

Dragoo, M. R. Resin ionomer and hybrid ionomer cements: Part II Human clinical and histologic wound healing responses in specific periodontal lesions. Int. J. Periodontics Restorative Dent., 17:75-87, 1997.

Farik, B.; Munksgaard, E. C.; Andreasen, J. O. \& Kreiborg, S. Fractured teeth bonded with dentin adhesives with and without unfilled resin. Dent. Traumatol., 18:66-9, 2002.

Flores, M. T.; Andersson, L.; Andreasen, J. O.; Bakland, L. K.; Malmgren, B.; Barnett, F. et al. Guidelines for the management of traumatic dental injuries. I. Fractures and luxations of permanent teeth. Dent. Traumatol., 23:66-71, 2007.

Fuks, A. B.; Chosack, A.; Klein, H. \& Eidelman, E. Partial pulpotomy as a treatment alternative for exposed pulps in crown-fractured permanent incisors. Endod. Dent. Traumatol., 3:100-2, 1987.

Glendor, U. Epidemiology of traumatic dental injuries -12 year review of the literature. Dent. Traumatol., 24:603-11, 2008.

Gomes, S. C.; Miranda, L. A. M.; Soares, I. \& Oppermann, R. V. Clinical and histologic evaluation of the periodontal response to restorative procedures in the dog. Int. J. Periodontics Restorative Dent., 25:39-47, 2005.

Grossman, L. I. Intentional replantation of teeth. J. Am. Dent. Assoc., 72:1111-8, 1966.

Heda, C. B.; Heda, A. A. \& Kulkarni, S. S. A multi-disciplinary approach in the management of a traumatized tooth with complicated crown-root fracture: a case report. J. Indian Soc. Pedod. Prev. Dent., 24:197-200, 2006.

Hu, L. W.; Prisco, C. R. D. \& Bombana, A. C. Knowledge of Brazilian general dentists and endodontists about the emergency management of dento-alveolar trauma. Dent. Traumatol., 22:113-7, 2006.

Mackie, I. C. \& Quayle, A. A. Alternative management of a crown root fractured tooth in a child. Br. Dent. J., 173:60-2, 1992.

Marcenes, W.; Beiruti, N.; Tayfour, D. \& Issa, S. Epidemiology of traumatic injuries to the permanent incisors of 9-12 yearold schoolchildren in Damascus, Syria. Endod. Dent. Traumatol., 15:117-23, 1999.

Marcenes, W.; Alessi, O. N. \& Traebert, J. Causes and prevalence of traumatic injuries to the permanent incisors of school children aged 12 years in Jarugua do Sul, Brazil. Int. Dent. J., 50:87-92, 2000.
Monteiro de Castro, M. A.; Poi, W. R.; Monteiro de Castro, J. C. \& Panzarini, S. R. Crown and crown-root fractures: an evaluation of the treatment plans for management proposed by 154 specialists in restorative dentistry. Dent. Traumatol., 26:236-42, 2010.

Murchinson, D. F.; Burke, J. T. \& Worthington, R. B. Incisal edge reattachment: indications for use and clinical technique. Br. Dent. J., 186:614-9, 1999.

Olsburgh, S.; Jacoby, T. \& Krejci, I. Crown fractures in the permanent dentition; pulpal and restorative considerations. Dent. Traumatol., 18:103-15, 2002.

Petersson, E. E.; Andersson, L. \& Sorensen, S. Traumatic oral vs non-oral injuries. Swed. Dent. J., 21:55-68, 1997.

Rappelli, G.; Massaccesi, C. \& Putignano, A. Clinical procedures for the immediate reattachment of a tooth fragment. Dent. Traumatol., 18:281-4, 2002.

Raslan, N. \& Wetzel, N. E. Exposed human pulp caused by trauma and/or caries in primary dentition: a histological evaluation. Dent. Traumatol., 22:145-53, 2006.

Rodd, H. D.; Malhotra, R.; O’Brien, C. H.; Elcock, C.; Davidson, L. E. \& North, S. Change in supporting tissue following loss of a permanent maxillary incisor in children. Dent. Traumatol., 23:328-32, 2007

Santos Filho, P. C. F.; Quagliatto, P. S.; Simamoto, P. C. Jr. \& Soares, C. J. Dental trauma: restorative procedures using composite resin and mouthguards for prevention. J. Contemp. Dent. Pract., 8:89-95, 2007.

Sengun, A.; Ozer, F.; Unlu, N. \& Otzurk, B. Shear bond strengths of tooth fragments reattached or restored. J. Oral Rehabil., 30:82-6, 2003.

Traebert, J.; Peres, M. A., Blank, V.; Bôell, R. S. \& Pietruza, J. A. Prevalence of traumatic dental injury and associated factors among 12-year-old school children in Florianapolis, Brazil. Dent. Traumatol., 19:15-8, 2003.

Yilmaz, Y.; Guler, C.; Sahin, H. \& Eyuboglu, O. Evaluation of tooth-fragment reattachment: a clinical and laboratory study. Dent. Traumatol., 26:308-14, 2010.

Correspondence to:

Jaime Andrés Díaz Meléndez

Departamento Odontología Integral,

Facultad de Medicina, Universidad de La Frontera.

Manuel Montt $112,4^{\circ}$ piso,

Telefonos 56-45-325775 / 56-45-734131

casilla 54-D

Temuco,

CHILE.

E-mail : felicar@hotmail.com ajans@ufro.cl

Received: 22-12-2011 Accepted: 18-01-2012 